ments showed that at $1 \cdot 2^{\circ} \mathrm{K}$. the vapour pressure of helium-3 was thirty-five times that of helium-4; helium-3 was suitable for thermometry at low temperatures down to $0.5^{\circ} \mathrm{K}$. and perhaps lower; the normal boiling point of helium-3 was $3 \cdot 2^{\circ} \mathrm{K}$., and by extrapolation to the critical temperature the critical pressure was $875 \mathrm{~mm}$. of mercury. A value of $0: 34 \mathrm{l} \mathrm{gm}$./c.c. for the critical density was deduced. Birds in London

IN April 1947 Anister of Works appointed a Committee of Bi d Sanctuaries in the Royal Parks (England atd Wales). For its general objectives the Committee recided to: (1) make suggestions for increasint the resident population of birds, their nuy ber and variety; (2) make suggestions for attracting migratory birds and for inducing unusual visitors to stay longer; (3) select competent persons as observers and reporters.

The Committee has now reported, and the results of its deliberations have been set out in a pamphlet, "Birds in London" (H.M. Stationery Office. 9d.). The first duty was the appointment and guidance of competent observers, and it is their statements which provide most of the material in the pamphlet. They show how successful has been the policy of developing the London bird sanctuaries, which were originally seypo so long ago as 1923.

\section{Youhg children}

To mark the y ir of its silver jubilee, the Nursery School Assgdiation of Great Britain has begun the publicatipn a new quarterly journal. This follows the forntion of the World Council of Early Childhood Ed vcation after an international meeting in Prorue, in August 1948, and the new journal is interled to act as a link between all who are interested in the education of young children in any part of the world. Volume I of Young Children contains articles on the use of water play in the nursery, the stages of education which follow the nursery school and the links between home and school. The new journal has been produced unpretensively and should strengthen a side of education which has been much neglected by existing journals. It is doubtful, however, if the new journal will survive unless the price is reduced.

\section{Hundredth Meeting of the Genetical Society}

THE Genetical Society of Great Britain, founded in 1919 by W/liam Bateson, will hold its hundredth meeting garing June 30-July 1, in Cambridge. To mark the occasion guest speakers will review the early gays of genetics, and there will also be comprehonsive demonstrations of genetical work now in progress in Great Britain. Genetical societies abroad have been informed of this meeting, to which all geneticists are cordially invited. Details may be obtained from the secretaries, G. Pontecorvo, Department of Genetics, University, Glasgow, W.2, or H. G. Callan, Institute of Animal Genetics, Unizensity, Edinburgh 9.

\section{The Night Sky in April}

FuLt moon occurs on April 13d. 04h. 08m., U.T., and new moon on April $48 d .08 \mathrm{~h}, 02 \mathrm{~m}$. The following conjunctifl with he moon take place: April 9d 13h., Saturn $3{ }^{\circ}$.; A April 20d. 03h., Jupiter $5^{\circ}$ N.; Aprl $29 \mathrm{~d}$. 2ho Mercury $0.7^{\circ} \mathrm{S}$. Mercury is in supe $10 \mathrm{r}$ conf ction on April 13 and is not favourabluplaced for observation until later in the month; the planet sets $1 \mathrm{~h} .45 \mathrm{~m}$. after the sun on April 30 , and can be seen in the western sky. Venus, in superior conjunction on April 16, is too close to the sun for favourable observation throughout the month. Mars rises about the same time as the sun during April, and cannot be observed. Jupiter is a morning star, rising at $3 \mathrm{~h} .20 \mathrm{~m} ., 2 \mathrm{~h} .30 \mathrm{~m}$. and $1 \mathrm{~h} .35 \mathrm{~m}$, at the beginning, middle and end of the month, respectively, and can be seen low down for a few hours before sunrise. Saturn sets in the early morning hours and is visible throughout the greater part of the night. Occultations of stars brighter than mag nitude 6 are as follows: April 1d. 19h. 46 3m., 45 Arie. $(D)$; April 7d. 00h. 31.4m., c Gemi. (D) ; April 11d. 20h. $56 \cdot 3 \mathrm{~m}$., $\eta$ Virg. $(D) . \quad D$ refers to disappearance, and the latitude of Greenwich is assumed. The Lyrid meteor shower is active about April 18-24. A total eclipse of the moon, visible at Greenwich, takes place on April 13, the circumstances of which are given as follows: moon enters penumbra, 01h. $31 \cdot 6 \mathrm{~m}$.; enters umbra, 02h. $27 \cdot 7 \mathrm{~m}$.; total eclipse begins, $03 \mathrm{~h} .28 \cdot 0 \mathrm{~m}$.; middle of eclipse, $04 \mathrm{~h} .10 \cdot 9 \mathrm{~m}$.; total eclipse ends, $04 \mathrm{~h} .53 \cdot 8 \mathrm{~m}$.; moon leaves umbra, $05 \mathrm{~h}$. $54 \cdot 1 \mathrm{~m}$.; leaves penumbra, $06 \mathrm{~h} .50 \cdot 3 \mathrm{~m}$. A partial eclipse of the sun, visible at Greenwich, occurs on April 28, its magnitude being 0.41 at Greenwich, where it begins at $6 \mathrm{~h} .21 \mathrm{~m}$., reaches its greatest phase at $7 \mathrm{~h} .15 \mathrm{~m}$., and ends at $8 \mathrm{~h} .14 \mathrm{~m}$.

\section{Announcements}

ON the joint recommendation of the presidents of the Royg Society and the Institution of Civil Enginee s, the Council of the Institution of Civil Engincers has awarded the James Alfred Ewing Megal for 1948 to Sir Edward Appleton. The medal is awarded annually, and was founded in 1936 in memory of Sir Alfred Ewing. This award has come appropriately when Sir Edward has just taken up his appointment as vice-chancellor of the University of Edinburgh, a position which Sir Alfred Ewing occupied with such distinction.

DR. R. P. LINSTEAD, director of the Chemical Resear Laboratory, Teddington, since 1945, has accepted the invitation of the University of London to succeed Sir Ian Heilbron as professor of organic chemistry and director of the Organic Chemistry Laboratories at the Imperial College of Science and Technology as from April 1, or as soon afterwards as can be arranged.

M. Gaston Dupoux has been elected correspondant for the Section of General Physics of the Paris Acgdemy of Sciences in succession to Prof. W. J. de Haas, who has been elected a foreign associate.

A DIvisron of the Royal Aeronautical Society has recently been formed in South Africa on the same lines those formed in Australia and New Zealand in O tober 1948. Associate fellows will still be elected by the parent body of the Society in London; but otherwise these Divisions of the Commonwealth will possess a fully self-governing status and will be free to develop along their own national lines.

THE Royal Photographic Society will be holding its annual exhibition at 16 Princes Gate, London, S.W.F, in two parts : part 1 (pictorial and colour), Seplember 9-October 2; part 2 (scientific, Nature, medical, record, press, commercial, industrial, techfical and radiographic), October 8-26. Admission will be free. Entries must be received by July 23, and entry forms may be obtained from the Secretary at the above address. 